\title{
Teachers and educational policies: negotiating discourses of male role modelling
}

Marie-Pierre Moreau, University of Roehampton, School of Education, Roehampton Lane, London, SW155PJ, UK, marie-pierre.moreau@roehampton.ac.uk (corresponding author)

Simon Brownhill, University of Cambridge, Faculty of Education, 184 Hills Road, Cambridge, CB2 8PQ, UK, spb55@cam.ac.uk

\begin{abstract}
Since the 1990s there has been some considerable discussion in English education policy of boys' underachievement and of male teachers serving as 'role models'. Drawing on two separate research projects, this article explores the diverse ways in which individual teachers negotiate discourses of role modelling, while also considering the performative nature of these discourses and some of their effects on teachers. The article shows that discourses of role modelling retain some currency among teachers and highlights the need for contemporary research on equality issues to inform the work of both policy-makers and teachers.
\end{abstract}

Keywords: teachers, gender, role models, education policy, England

This research did not receive any specific grant from funding agencies in the public, commercial, or not-for-profit sectors. 


\section{Introduction}

Since the 1990s there has been some considerable discussion in education policy of boys' underachievement and, related to that, of male teachers serving as 'role models'. Such discussion has unfold across the 'Global North’, including Australia, Canada, Ireland, New Zealand, the UK and the United States (see Bouchard and Saint-Amant, 1996; Gilbert and Gilbert, 1998; Mills, 2005; Moreau, 2014; McCormack and Brownhill, 2014). This concern has been particularly vivid in England (Epstein et al., 1998; Skelton, 2002; Francis and Skelton, 2005; Skelton et al., 2007; Hutchings et al., 2008; Brownhill, 2014, 2015b), where a wealth of policy initiatives have been implemented (see, for example, DfES, 2004; DfES, 2005a; DCSF, 2009). Whilst there has been a noted reduction in the prominence of this 'policy drive' in the recent years, discussions of role modelling retain some currency in the public and professional arenas with the notion of role model itself having become part of a 'common-sense' discourse (Lyndon, 2015; Robb et al., 2015; Tarrant et al., 2015).

In England, where the research reported in this article was conducted, discussions of role modelling have been overwhelmingly related to concerns about boys' underachievement, although they have also been linked to girls' and women's under-representation in STEM subjects and careers (Marchetti and Raudma, 2010; MacDonald, 2014). Despite the fact that what a 'role model' means is often left undefined, discussions of role modelling in English education policy have usually been underpinned by a constant set of assumptions. In particular, it has been claimed that boys are 'underachieving', that students see their teachers as 'role models', and that providing boys with samesex teaching role models will have a positive effect on their sense of identity, their behaviour and their educational attainment (see discussions in Hutchings, 2002; Francis et al., 2008; Moreau, 2011a). In England, this discourse of role modelling also coexists and interconnects with a discourse of 'feminisation', which constructs the presumed statistical and normative feminisation of the teaching profession and of school cultures as a 'problem', while male teachers and the 're-masculinisation' of teaching are presented as the solution (see discussions in Pepperell and Smedley, 1998; Skelton, 2002; Moreau, 2014). Such discussions need to be relocated in the broader national and international context of a 'backlash' discourse (Faludi, 1991) claiming that women and other dominated groups are now in a dominant position. 
Despite the considerable amount of policies and research articles dedicated to this topic, a relatively modest body of work has explored how teachers actually engage with the discourse of role modelling. Not only is this surprising, but this dearth of research is also problematic. Indeed, the views that teachers and school leaders hold about gender and other equality matters have been found to influence the formers' pedagogical practices and the latters' decisions about staff recruitment, deployment and promotion (Spender, 1982; Skelton, 2002; Moreau et al., 2008) - all matters which in England have been increasingly devolved to school level.

The theoretical approach underpinning this article is similar to the one adopted in our earlier work (e.g. Moreau, 2011a) and draws on a social constructivist perspective informed by feminist poststructuralist theories of gender in education (Connell, 1987; Skelton and Francis, 2009). According to this approach, gender is conceptualised as a relationship of power (Le Feuvre, 2008). Centre stage is given to the concept of discourse, conceptualised as a set of social practices which are performative rather than descriptive (Foucault, 1969). Discourses produce subjectivities, while at the same time subjects constantly engage in negotiating and resisting discourses and their own discursive positioning within these.

This article pursues a dual purpose. First, it explores the ways in which individual teachers engage with discourses of role modelling. Second, it considers the performative nature of discourses, including their material, psychological and social effects (Henriques et al., 1984; Francis, 2006). In doing so, it acknowledges the need 'to resist the inscriptions that draw us towards some unproblematised acceptance of the "truth”' (Raphael Reed, 1999: 93), while simultaneously considering the effects of such 'truths' (Moreau, 2011a).

\section{Research and policy context}

In the 1970s and 1980s, UK policy concerns around gender and education focused on girls' attainment, subject and career choices. Around the same period of time, a significant body of work looked at the 'hidden curriculum' of schools and at its effects on girls (Sharpe, 1976; Deem, 1980; Griffin, 1985; Mahony, 1985; Stanworth, 1987; Woods, 1990). From the 1990s onwards, this focus shifted to boys who were thought to be underachieving in the midst of a 'crisis of masculinity'. 
Related to this policy shift, a significant body of work started to question the claims underpinning discourses of role modelling, highlighting in particular the lack of supporting evidence and their uncertain theoretical basis (Epstein et al., 1998; Carrington et al., 2005; Francis and Skelton 2005; Hutchings et al., 2008; Arnot and Mac an Ghaill, 2006; GEA, 2009; Moreau, 2011a). Despite a lack of evidence and, more recently, of the emergence of a body of work highlighting that teachers' gender has no impact in most contexts on students' attainment (Lam et al., 2010; Neugebauer et al., 2010; Helbig, 2012), many policy-makers did, and continue to argue, that the statistical and normative feminisation of teaching deprives boys from role models, ultimately causing their underachievement (DfES, 2005a). The interconnectedness between the discourse of role modelling and the discourse of the feminisation of schools is well-exemplified in a declaration of Anthea Millett, the former Chief Executive of the Teacher Training Agency (TTA), who argued that 'The feminisation of the [teaching] profession leads to an absence of male role models for many of our pupils, particularly those from the majority of one parent families' (Millett, 1999: 2). Views such as Millet's construct the feminisation of the teaching workforce as a problem that needs to be fought, as it allegedly deprives children from male teachers, brings into schools 'feminine values' which are seen as necessarily endorsed by women and girls, and threatens the professional status of teaching. In comparison, male teachers are presumed to provide (positive) role models for boys, as their physical presence is presumably sufficient to improve boys' sense of identity, behaviour and attainment (Robb et al., 2015).

In England, these concerns have characterised all the governments in place since the late 1990s, with some unusually consensual views on the topic across the political spectrum (for a more detailed account of this, see Moreau, 2011a). After the New Labour government arrived in power in 1997, the Green Paper Teachers: Meeting the Challenge of Change (DfEE, 1998) revealed how governmental concerns for the 'modernisation' of the profession and its 'remasculinisation' meshed together. Over the years, this concern persisted. In 2002, the TTA launched a campaign to attract more men. A few years later, its successor, the now defunct Teacher Development Agency (TDA), aimed to attract candidates from 'under-represented groups' to teaching, referring inter alia to men (TDA, 2007). David Blunkett, then Secretary of State for Education and Employment, claimed that underachievement was 'linked to a laddish culture' and called for 'better role models in our schools 
and society more generally' (DfEE, 2000, cited in Carrington and Skelton, 2003: 254). Damian Green, then Shadow Education Secretary, expressed some similar concerns (BBC, 2002) and so did the then General Secretary of the National Association of Head Teachers, David Heart: 'We're going to face a catastrophic situation over the next five years. We can't afford to let teaching become an all-female profession. It will cause long-term damage to the education of boys, of that there's no doubt' (cited in Pyke, 2000). In some instances, concerns for boys intersected with race and class, with, for example, 'Black boys' and 'White working-class boys’ specifically mentioned (Abbott, 2002; Meikle, 2007). Over the years, policy-makers have devoted some extensive resources to improving boys' attainment and to attracting and retaining male teachers, including the creation of the now defunct Gender and Achievement website primarily focusing on boys' underachievement, the production of guidance documents targeting school head teachers and teachers (e.g. DfES, 2005b), with also a number of Ofsted reports published on the topic (Ofsted, 1996, 2003a, 2003b) and research commissioned in this area (e.g. Younger et al., 2005; DfES, 2007). Such concerns have also been picked up extensively by the media (see Meikle, 2007) and by higher education institutions, a number of which offer bursaries to men enrolled on teacher education programmes. From the late 2000 onwards, discussions of role modelling seem to have lost their past prominence, yet retain some currency and continue to permeate governmental, media and public discourses, albeit in a more insidious and pervasive form (see, e.g., DfE, 2013; Weale, 2015).

\section{Methodological framework}

The data discussed in this article arise from two separate research projects: a cross-national comparative study of gender inequalities in the secondary school teaching profession in England and France (Moreau, 2009, 2011b), referred hereafter as Project 1, and a study of the experiences of men working in the early years sector (0-8) in England (Brownhill, 2011, 2015a), referred hereafter as Project 2. The unique grouping of these projects gives this article a wider scope which enables us to look at the way discourses of role modelling circulate and are taken up or resisted by individual teachers, in a range of educational settings.

The first project (Moreau, 2011b) generated 60 in-depth, semi-structured interviews, half of 
which were conducted with secondary school teachers working in England and are used for the purpose of this article. The other half were conducted with secondary school teachers working in France. However, none of the French participants made reference to role modelling or boys' underachievement, with also very limited discussions of this in policy circles (something we have explored in a separate paper - see Moreau, 2011a); as such the French fieldwork was discarded. The project focused on gender and career progression, with a similar proportion of men and women being interviewed, all of them qualified teachers aged between 30 and 50. Apart from the gender and age criteria, the recruitment of participants sought diversity rather than representativeness in relation to variables likely to influence their experiences (i.e. geographical area, type of job, type of school, subject taught and family circumstances). Sampling operated through a snowballing method (Blanchet and Gotman, 1992). Interviews transcripts were subject to a thematic analysis (Robson, 1993). Themes were refined following a careful reading of the transcripts with the identification of sub-themes (Moreau, 2011b). The data on which this article draws were identified through a search of key words (i.e. role model, feminised, feminisation) and through a careful reading of the interview transcripts, with data coded under two themes identified for the specific purpose of this article: discourses of role modelling and the effects of these discourses.

The second research project informing this article focused on capturing the voices of men working in the early years sector (defined as educational provision for children aged 0 to 8 years old) in a county in the East of England (Brownhill, 2011, 2015a). The research embraced a mixed-method staged approach (Tashakkori and Teddlie, 2003; Clough and Nutbrown, 2007). At Stage One of the project, male participants were drawn from a list of early years providers in the county and were invited to complete a postal questionnaire. Eighty-four questionnaires were returned by a range of early years male practitioners who were working either as qualified early years teachers, nursery nurses, teaching assistants or after-school providers, or were training to be teachers in the $0-8$ sector. At Stage Two a focus group interview was conducted with a sub-sample of three men who were, or who had experience of, working in a senior management position in primary school settings. This article draws specifically on the focus group material, although the analyses are also broadly informed by the questionnaire data. The analytical method used for this second project mirrors the approach 
adopted in the first project in terms of searching for key words and the coding of data under the two specific themes as previously mentioned.

\section{Teachers negotiating discourses of role modelling}

Since teachers as role models was a key focus of Project 2 (Brownhill, 2011), it is maybe unsurprising that participants to this project discussed this notion at length. In comparison, participants in Project 1 (Moreau, 2009, 2011) were not asked directly about role modelling. However, five of them (out of 30) mentioned it spontaneously. While policy discussions of role modelling have primarily focused on primary schools, this implies that this discourse has been 'taken up' by teachers at other levels of the school system, though not necessarily in an overwhelming way (Lumpkin, 2008).

Overall, interviewees' narratives identified being a role model as a central and positive component of their professional identity, although it also came with some challenges - a point to which we come back later in this article. For example, in the following excerpt, being a role model is presented as a positive historical shift and incorporated into a narrative of 'progress' - from an authoritarian, discipline-driven pedagogical relationship to leading by example through respect and good behaviour:

There is a change I think. Eighteen years ago discipline was a little different to now. I think you could sometimes then just shout quickly to get them quiet and they would be. You could then be nice to them. I think now if I were to shout at a girl she might shout back... I think now... you've got to lead by example. If I'm trying to teach young children and young adults how to behave, then I must model that good behaviour myself and treat them with some respect and expect it back as well. (Jack, Secondary, Project $1)^{1}$

The notion of role model has been criticised for being fuzzy and polysemous (Casper and Schultz, 1999) and indeed, interviewees did not always provide a clear definition of the term. However, discussions across the two projects converged in acknowledging that this notion promotes the idea of

\footnotetext{
1 Pseudonyms are in use throughout the article.
} 
copying or imitating someone - a view which implicitly positions children as passive and powerless in the learning process, and teachers as agentic and powerful (Walkerdine, 1990):

I think [the role model is] someone who through their behaviour is... seen as... providing a positive example to others. (Ben, Primary, Project 2)

...in its most simplest term it's just something that you'd want children to copy... behaviours... attitudes, values, actions, words, relationships... and I think that's how children probably see it, they try to copy $\mathrm{Mr}[\mathrm{X}]$ or copy $\mathrm{Mr}$ [Y]. (Will, Primary, Project 2)

Discussions of role modelling also appeared to be underpinned by a number of shared assumptions. Some of these assumptions echoed policy discourses, including the views that: pupils need role models, teachers provide (positive) role models to pupils, and having a role model has a positive impact on pupils, in terms of attainment, behaviour and identity formation. The term 'role model' was seen as relevant to teachers of both gender groups. As one teacher put it: I think being a teacher is being a role model, whether you're male or female, you're still a role model (Alan, Primary, Project 2). Yet discussions rarely referred to women as role models, again reflecting policy concerns for the presumed lack of male role models in schools.

However, some discrepancies were also found among participants' views of role modelling. In particular, its gender-matching component attracted some divergent views. Three main narratives were identified in relation to this aspect. The first narrative altogether resisted the view that students adopt same-sex role models and that the gender-matching of students and teachers is a desirable ambition. Albeit embracing the binary categorisation of gender, this narrative acknowledged the construction of identities as multiple and intersectional:

...the girls that we teach, they don't fit into little compartments...some of them respond better to females and some of them respond better to males. Some of them have a father at home and some of them don't. ... and so, you know, because there are a lot of different teachers, lots of different ethnicities, lots of different, you know, male and female...in the end there is something for all the girls. (Christopher, Secondary, Project 1) 
I think there can be excellent teachers both male and female and there are at this school and my old school I was at and I'm sure in every school in the country. I don't think it makes any difference. I think good female teachers can relate to boys and the male teachers can relate to girls and that happens quite a lot. (Matthew, Secondary, Project 1)

A second narrative reproduced the view that pupils choose same-sex role models and that gender-matching is a desirable occurrence. By arguing that women are better role models for girls and men for boys, this narrative is underpinned by an essentialist, one-dimensional and fixist conception of gender, as women are thought to have more in common with other women/girls, and men with other men/boys, independently from their other identities.

I suppose with PE [Physical Education], as a man doing PE it [gender] always is going to influence it because (a) the sports you're doing but also the boys look up to you as some kind of a sporty chap, role model. (Jack, Secondary, Project 1)

A third narrative assumed that boys as well as girls would benefit from being taught by men, although this was not always stated explicitly. For example, interviewees would use the gender neutral term 'kids' but talked more gender-specifically about male teachers, suggesting that male teachers were 'positive' role models for boys and for girls without ever applying the same rhetoric to women teachers:

I think good male role models, and I would stress the 'good', can have a really good impact because I don't think it's just good for boys; I think some of my most favourite, the children who most latch onto me are the girls. I think that's because I'm not aggressive... (Ian, Early Years, Project 2)

It is worth noting here how this third narrative feeds into the wider discourse discussed earlier, which constructs the feminisation of teaching (and women teachers themselves) as 'the problem' while its masculinisation becomes ‘the solution’ (Pepperell and Smedley, 1998). In England and other countries across the 'Global North', the feminisation of teaching has recurrently been blamed by policy-makers and the media for the loss of prestige and the (presumed) de-professionalisation of teaching, while women teachers have been accused of lacking authority, ambition and commitment (see examples in 
Millett, 1999; Wansell, 2001; Symeonidis, 2015). Conversely, attracting men has been described as countering these issues (Gove, 2011). Some interviewees took up this deficit discourse of women teachers:

...in primary I think it's loaded to females and I don't think that's a good thing for the kids. (Ashton, Secondary, Project 1)

In my last school...it was an all-girls school... there were far more women teachers than men, and I think that gave the students a very skewed view on life. It wasn't a healthy outlook, because it was dominated by too many women. (Kathleen, Secondary, Project 1)

\section{The gendered effects of role modelling theories on teachers}

Discourses are not solely rhetorical matters and can have multiple effects on people's lives (Henriques et al., 1984; Raphael Reed, 1999; Francis, 2006). As discussed above, in England the view that male role models could bring benefits for boys (and sometimes girls), including in terms of tackling their 'underachievement', has resulted in the mobilisation of a wealth of resources to support the policy view (Moreau, 2011a). Likewise, the narratives of our research participants suggest that discourses of role modelling influence teachers', school managers' and sometimes parents' views and practices in a range of ways.

Men teachers in particular talked of the challenges associated with being seen as a role model, which can be largely attributed to the fact that, as noted earlier, the policy discourse focuses on this gender group. With teachers now regarded as role models, their behavioural, presentational and moral characteristics attract considerable attention compared with what can be observed in other professions (Lunenberg et al., 2007). As a result, participants discussed feeling pressured in adopting and conforming to certain (gendered) ways of being. While the notion of who teachers are and how they behave has always been a concern (see Bullock, 2015), and while women teachers' private lives and bodies in particular have historically been subjected to high levels of surveillance (Oram, 1989; Tamboukou, 2003; Mallozzi, 2014), including self-surveillance, male teachers’ narratives suggest that such scrutiny has extended to them, possibly under the influence of role modelling theories and in 
conjunction with other discourses positioning them as potential child abusers and sexual predators (Jones, 2004; Cushman, 2010).

....and the other thing that strikes me about the whole concept [of role model] is that it's a sort of double edged sword...it comes with a burden that I've got a job to do here...and maybe I ought to be a male role model, [but] I'd rather just be a teacher thanks, don't...don't label me with male or role model at all thanks or...or perhaps I'll just be a role model to the extent that all teachers are but perhaps you know...some people don't want to get into that - that's a gender issue. (Ben, Primary, Project 2)

Related to the above, the expectations that male teachers behave as 'proper men', i.e. adopt the characteristics broadly associated with dominant, heterosexual masculinities, while also being caring but avoiding the discursive position of the sexual predator, often proved difficult to navigate and exacerbated the need for panopticonic self-discipline (Foucault, 1982). As argued by Jones (2004: 53), in a context in which the demands of a risk-management culture (Beck, 1992) have intensified 'the risk of sex abuse accusation is one of many risks that now must be managed by teachers'. Men working in early years settings were particularly confronted to this due to the apparent contradiction between doing masculinity and doing care work:

... you are expected to be this male role model and this caring teacher but I'm more wary about the way that...that I am with those children and being careful about the things that I do to the children that you could quite easily go in and see a female teacher doing, for example sitting a child on your knee or, erm...or going into a toilet... (Alan, Primary, Project 2)

The way gender relationships play out in schools mean that male teachers were often allocated tasks that were socially constructed as masculine, for example organising sports activities and lifting and carrying heavy objects. As Ben (Primary, Project 2) argued, '[You hear things like] "Could you get something heavy down off the shelf?" and "You'll be doing the football team then!” and [you have] all of these expectations on you as a member of staff as well and...and suddenly you're sort of pigeon holed.' However, the gendered division of school labour also worked in ways reasserting male privilege, for example when parents associated male teachers with authority and positioned them as 
powerful enough to compensate for deep-seated inequalities, in sharp contrast with the long-lasting association between women and the devalued and misrecognised aspects of teaching work (Acker, 1995; Moreau et al., 2008). While the gendered division of school labour and the association of men with authority in particular have preceded the emergence of discourses of role modelling, this rhetoric appears to further justify these, as exemplified by Will's narrative:

...my children who come from very socially disadvantaged backgrounds, you know, they come from dysfunctional families, they don't have stable role models in their lives and that does have a very negative impact on them and parents will often come into me and say 'Mr [X], can you talk to them because you're a man'. You know and I've had that said to me: 'You're a man; they'll listen to you'. (Will, Primary, Project 2)

As has been demonstrated elsewhere (see Simpson, 2004), men's careers do benefit from their minority status, with, in the case of teaching, discourses of role modelling reinforcing male privileges. Indeed, interviewees' narratives suggested that these discourses could positively influence decisions regarding the recruitment and promotion of male staff. In particular, practices of positive discrimination towards men in schools seemed to be common knowledge (see also Blau and DeVaro, 2006; Moreau et al., 2008):

I think we need men, definitely....I actually did two weeks in a primary school, and the guy...they had one...apart from the Head Teacher, well the deputy Head...there was one male teacher there and he was like gold dust. Apparently, wherever he went, he would get a job, because he was rare, because...first of all, he was a black guy...and male and black...you don't get many of those in schools. (Kimberley, Secondary, Project 1)

I did think about re-training as a primary school teacher and one of the things people said to me was, 'Oh, when you do that you become a Head really quickly because men do, you know', which is true I think. So I think definitely in primary education, men jump up the...become Heads much quicker. It's kind of...it's not equal. (Thomas, Secondary, Project 1). 
While the effects of discourses of role modelling are worrying from a feminist perspective, as they imply the differential treatment of men and women and undermine women teachers, it is also worth noting here that this is only one of the many discourses deployed in teachers' narratives. Interestingly, many also drew on a discourse of equal opportunities to emphasise that recruitment and promotion procedures should be meritocratic, rather than be driven by the need to attract and retain more men. This positioning of male and female teachers at the intersection of several discourses is likely to have mitigated the negative effects of the discourses of role modelling previously discussed in this article:

I wish there were more men at our primary schools as I think it would make things much easier for children as well, especially children who don't have a male role model at home. But I don't know that that is going to happen. I don't know what the answer is. But I do think that schools are generally trying very hard to promote equality and to try and promote equally. But at the same time, you have got to promote people into those jobs who can do the jobs, that are...you know, you've got to also have people on their merit and if a man is better with a job than a woman because they are better for it, then you should appoint them and you shouldn't be dictated to by gender. I think teaching is too important really for that. It should be more open-minded, you know, and it should be based on merit not gender at all, because it's the kids that lose out. (Emma, Secondary, Project 1)

\section{Discussion}

This article set out to explore the way individual teachers engage with discourses of role modelling and to consider some effects of these discourses on teachers. As noted, in recent years such a rhetoric has become more subdued in media and policy circles. However, this article adds to a body of evidence which highlights that discourses of role modelling continue to circulate, albeit in more pervasive ways, including in the narratives of male and female teachers and at various levels of the education system, from early years to secondary schools. In England, where the research reported in this article was conducted, policy claims about role modelling have often been underpinned by a fixed 
set of assumptions spelled out in the introduction to this article. A key finding from this article is that, while some teachers reproduce the dominant policy script about role modelling, others deviate from it. There is a general consensus among participants that pupils need role models and that teachers can effectively fulfil that need. However, different narratives were identified regarding the gendermatching component of the discourse of role modelling. Some participants resisted the view, widespread in policy and media circles, that students adopt same-sex role models and that the gendermatching of teachers and students is desirable. Others claimed that pupils choose same-sex role models, with gender-matching being a sought-after occurrence. A third type of narrative suggested that both boys and girls would benefit from being taught by male teachers, although this was not always stated explicitly.

Thus, while the notion of role model has become part of a 'common-sense' discourse (Robb et al., 2015), it is also clear that teachers do not passively reproduce the dominant policy frame. Role modelling discourses are taken up in different ways by different teachers, as they negotiate specific components (in this case, gender-matching) of the discourse of role modelling. So as to grasp the complexity of the relationship between teachers' narratives and the 'policyscape' (Ball, 1998), it appears useful to conceptualise policy discourses as ‘conceptual repertoires’ (Burr, 1995), which can be drawn upon as a resource. Policy discourses are encoded/decoded by teachers (Hall, 1973) and enmeshed with other resources available to them as they form their own hybrid views of their environment and professional identity.

This article also adds to a body of research highlighting the continuing effectiveness of the discourse of role modelling. First, it brings about some intensive surveillance of teachers' behaviour and morality, as role modelling discourses posit that these are 'taken up' easily by pupils. While there is a long-standing concern for who teachers are, historically it is mostly women who have been exposed to such surveillance (see Oram, 1989; Tamboukou, 2003; Kelleher, 2011; Mallozzi, 2014). Discourses of role modelling, with their focus on men, as well as discourses constructing men working with young children as sexual predators (Jones, 2004), have extended this surveillance to men. This appears to be a source of social anxiety for some - in the context of school risk-management cultures, an economy of visibility (Foucault, 1982) develops which requires from male teachers that they are 
seen to perform a 'safe' teacher identity and a 'safe' masculinity. Second, discourses of role modelling contribute to legitimate recruitment and promotion processes which favour men in ways which many consider to be discriminatory towards women, as men have become in the words of one participant, 'gold dust' and the solution to many of the problems faced by boys and, sometimes, even girls (Skelton, 2002; Moreau et al., 2008; Moreau, 2014). Third, the discourse of role modelling also affects more broadly the way we think about gender. The essentialist linking of women with 'feminine values' and of men with 'masculine values' in its dominant policy version reinforces the binary categorisation of gender as it asserts the existence of irreducible differences between both gender groups. Even more problematic, this gender binary is also constructed as a hierarchy as (teaching) masculinities are allocated a higher value than (teaching) femininities, with men positioned as remedies to the problems seemingly resulting from women and more generally from the feminisation of the profession (Pepperell and Smedley, 1998). Fourth, this discourse also tends to obscure the equality and well-being issues which affect various groups of teachers as, in policy circles, social justice concerns about this group tend to be driven by instrumental motives. Rather than defined as a power relationship, gender and other equality matters (such as race, particularly in the US context) becomes constructed as a commodity or as a form of human capital which is instrumentalised by policy-makers and school managers, as is the case when they recruit male teachers to improve students' performance. Often, there is limited consideration of how this commodification of equality matters affect teachers (Rezai-Rashti and Martino, 2010; Brown, 2012). Meanwhile, in England, other gender issues, such as women teachers' under-representation in leadership and management positions, tend to be absent from and simultaneously compounded by policy discourses (Moreau et al., 2008; Cushman, 2010).

Given the longevity of this 'drive' by policy makers, the dearth of research on the effects of discourses of role modelling and the lack of consideration for empirical evidence challenging the assumptions underpinning this discourse is surprising. While the access of men and women to all professions is an important component of gender equality, a 'buy in' to the 'men-are-the-answer' mind set by professionals is not only misguided but potentially damaging to teachers as well as to the education of future generations. In the light of this article and of recent scholarship in this area, of 
particular significance is the need to ensure that research on equality matters informs the work of policy-makers and of individual teachers. Among other things, this could be achieved through the inclusion of education policy and equality issues on teacher education programmes and continuing professional development, with this provision informed by recent research. Too often, discussions of being a role model remain broadly informed by 1950s functionalist and sex-role socialisation theories (e.g. Parsons and Bales, 1955; Merton, 1957) which, in research circles, have long been viewed as obsolete and simplistic when it comes to explain the way students' and teachers' identities are constructed, including in their gendered dimension (Connell, 1987; Britzman, 1993). In an effort to challenge ongoing discussions and the broader context of recuperative masculinity and backlash politics within which they are located (Faludi, 1991; Lingard and Douglas, 1999), these discussions need instead to be informed by recent empirical and theoretical work acknowledging the complexity, diversity and fluidity of subjectivities, and of the relationship between policy discourses, teachers and learners.

\section{References}

Abbott, D. (2002). Teachers are failing black boys. The Guardian, 6 January. Retrieved on 22 May 2016 from: http://www.theguardian.com/politics/2002/jan/06/publicservices.race.

Acker, S. (1995). Gender and teachers’ work. Review of Research in Education, 21, 99-162.

Arnot, M. and Mac an Ghaill, M. (Eds.) (2006). Gender and Education: A Reader. London: RoutledgeFalmer.

Ball, S. (1998). Big policies/small world: an introduction to international perspectives in education Policy. Comparative Education, 34(2), 119-130.

BBC (2002). Men wanted in primary schools. 22 April. Retrieved on 22 May 2016 from: http://news.bbc.co.uk/1/hi/education/1943295.stm

Beck, U. (1992). Risk society: towards a new modernity. London: Sage.

Blanchet, A. and Gotman, A. (1992). L'enquête et ses méthodes: l'entretien (collection 128). Paris: Nathan Université Sociologie.

Blau, F. D. and DeVaro, J. (2006). Gender, promotion, and raises: Sometimes the advantage goes to men (ILR Impact Brief \#15). Ithaca, NY: School of Industrial and Labor Relations, Cornell University. $\quad$ Retrieved on 22 May 2016 from: http://digitalcommons.ilr.cornell.edu/cgi/viewcontent.cgi?article=1026\&context=briefs 
Bouchard, P. and St-Amant, J. C. (1996). Garçons et filles: Stéréotypes et réussite scolaire [Boys and girls: Stereotypes and school performance]. Montréal: Editions du Remue-Ménage.

Britzman, D. (1993). Beyond rolling models: Gender and multicultural education, in S.K. Biklen and D. Pollard (Eds), Gender and education (pp. 25-42). Chicago: The University of Chicago Press.

Brown, A. L. (2012) On human kinds and role models: A critical discussion about the African American male teacher. Educational Studies: Journal of the American Educational Studies Association, 48(3), 296-315.

Brownhill, S. (2011). The 'brave' man in the early years (0-8): the ambiguities of being a role model. Unpublished EdD thesis, University of Derby.

Brownhill, S. (2014). 'Build me a male role model!' A critical exploration of the perceived qualities/characteristics of men in the early years (0-8) in England. Gender and Education, 26(3), 246261.

Brownhill, S. (2015a). The 'brave' man in the early years: the ambiguities of being a role model. Saarbrücken, Germany: LAMBERT Academic Publishing.

Brownhill, S. (2015b). The 'brave' man in the early years (0-8): defining the 'role model'. European Early Childhood Education Research Journal, 23(3), 370-379.

Bullock, M. (2015). What Makes a Good Teacher? Exploring Student and Teacher Beliefs on Good Teaching. Rising Tide, 7, 1-30.

Burr, V. (1995). An introduction to social constructionism. London: Routledge.

Carrington, B. and Skelton, C. (2003). Re-thinking 'Role Models': Equal Opportunities in Teacher Recruitment in England and Wales. Journal of Education Policy, 18(3), 1-13.

Carrington, B., Tymms, P. and Merrell, C. (2005). Role models, school improvement and the 'gender gap' - Do men bring out the best in boys and women the best in girls? Paper presented to the European Association for Research on Learning and Instruction, University of Nicosia. Retrieved on 22 May 2016

from:

http://www.cem.org/attachments/publications/CEMWeb019\%20EARLI\%202005\%20Role\%20Model s\%20School\%20Improvment\%20And\%20Gender\%20Gap.pdf

Casper, V. and Schultz, S. (1999). Gay parents/ straight schools. New York: Teacher's College Press. Clough, P. and Nutbrown, C. (2007). A Student's Guide to Methodology. $2^{\text {nd }}$ edn. London: Sage Publications.

Connell, R. (1987). Gender and Power: Society, the Person and Sexual Politics. Sydney: Allen \& Unwin.

Cushman, P. (2010). Male primary school teachers: Helping or hindering a move to gender equity? Teaching and Teacher Education, 26(5), 1211-1218.

DCSF (2009). Gender and Education - Mythbusters: Addressing Gender and Achievement: Myths and Realities. Nottingham: DCSF Publications. Retrieved on 22 May 2016 from: 
http://webarchive.nationalarchives.gov.uk/20130401151715/http://www.education.gov.uk/publication s/eOrderingDownload/00599-2009BKT-EN.pdf

Deem, R. (1980). Schooling for Women’s Work. London: Routledge \& Kegan Paul.

DfE (2013). New routes for talented ex-armed forces personnel to become teachers. Retrieved on 7 June 2016 from: https://www.gov.uk/government/news/new-routes-for-talented-ex-armed-forcespersonnel-to-become-teachers.

DfEE (1998). Teachers: meeting the challenge of change. Green Paper. London: DfEE.

DfES (2004). Ensuring the attainment of Black Caribbean boys: Key stage 3 national strategy. London: DfES.

DfES (2005a). Children's Workforce Strategy: A strategy to build a world-class workforce for children and young people. Nottingham: DfES Publications. Retrieved on 7 May 2016 from: https://www.education.gov.uk/consultations/downloadableDocs/5958-DfES-ECM.pdf

DfES (2005b). Ensuring the attainment of White working class boys in writing: Key stage 3 national strategy. London: DfES.

DfES (2007). Gender and education: The evidence on pupils in England. London: DfES.

Epstein, D., Elwood, J., Hey, V. and Mans, J. (1998). Failing Boys? Buckingham: Open University Press.

Faludi, S. (1991). Backlash: The undeclared war against American women. New York, NY: Crown.

Foucault, M. (1969). L’archéologie du Savoir. Paris: Gallimard.

Foucault, M. (1982). Discipline and punish: the birth of the prison. Harmondsworth: Penguin.

Francis, B. (2006). Heroes or zeroes? The discursive positioning of ‘underachieving boys' in English neo-liberal education policy. Journal of Education Policy, 21(2), 187-200.

Francis, B. and Skelton, C. (2005). Reassessing Gender and Achievement. London: Routledge.

Francis, B., Skelton, C., Carrington, B., Hutchings, M., Read, B. and Hall, I. (2008). A Perfect Match?

Pupils' and teachers' views of the impact of matching educators and learners by gender. Research Papers in Education, 23(1), 21-36.

GEA (2009). Gender and Education Association (GEA)'s Response to DCSF 'Gender Agenda' Initiative. May-June. Lancaster: Gender and Education Association. Retrieved on 31 September 2009 from: http://www.genderandeducation.com/files/GEAresponseFINAL_1.pdf

Gilbert, R. and Gilbert, P. (1998). Masculinity goes to school. Sydney: Allen and Urwin.

Gove, M. (2011). Speech: Michael Gove to the Durand Academy. 1 September. Retrieved on 2 July 2016 from: https://www.gov.uk/government/speeches/michael-gove-to-the-durand-academy

Griffin, C. (1985). Typical girls? Young Women from school to the Job Market. London: Routledge \& Kegan Paul.

Hall, S. (1973). Encoding and decoding in the television discourse. Birmingham University: Centre for Cultural Studies. 
Helbig, M. (2012). Boys do not benefit from male teachers in their reading and mathematics skills: empirical evidence from 21 European Union and OECD countries. British Journal of Sociology of Education, 33(5), 661-677.

Henriques, J., Hollway, W., Urwin, C., Venn, C. and Walkerdine, V. (1984). Changing the Subject: Psychology, Social Regulation and Subjectivity. London: Methuen.

Hutchings, M. (2002). A representative profession? In M. Johnson and J. Hallgarten (Eds.), From victims of change to agents of change: the future of the teaching profession (pp. 125-149). London: IDDR.

Hutchings, M., Carrington, B., Francis, B., Skelton, C., Read, B. and Hall, I. (2008). Nice and Kind, Smart and Funny: What Children Like and Want to Emulate in Their Teachers. Oxford Review of Education, 34(2), 135-157.

Jones, A. (2004). Social anxiety, sex, surveillance, and the 'safe' teacher. British Journal of Sociology of Education, 25(1), 53-66.

Kelleher, F. (2011). Women and the teaching profession: Exploring the feminisation debate. London: Commonwealth Secretariat.

Lam, Y. R., Tse, S. K., Lam, J. W. and Loh, E. K. Y. (2010). Does the gender of the teacher matter in the teaching of reading literacy? Teacher gender and pupil attainment in reading literacy in Hong Kong. Teaching and Teacher Education, 26, 754-9.

Le Feuvre, N. (2008). La pluralité des modèles de féminisation des professions supérieures en France et en Grande-Bretagne. In H. Hirata, M.R. Lombardi, M. Maruani (Eds) Marché du travail et genre. Comparaisons internationales (263-276). Paris: La Découverte.

Lingard, B. and Douglas, P. (1999). Men engaging feminisms: Profeminism, backlashes and schooling. Buckingham: Open University Press.

Lumpkin, A. (2008). Teachers as Role Models: Teaching Character and Moral Virtues. Journal of Physical Education, Recreation and Dance, 79(2), 45-49. Retrieved on 22 May 2016 from: http://www.csuchico.edu/kine/documents/teachersasrolemodels.pdf

Lunenberg, M., Korthagen, F. and Swennen, A. (2007) The teacher educator as the role model. Teaching and Teacher Education, 23(5), 586-601.

Lyndon, N. (2015). Why aren't we doing more to encourage men to be primary school teachers? The Telegraph, 12 June. Retrieved on 27 May 2016 from: http://www.telegraph.co.uk/men/thinkingman/11668169/Why-arent-we-doing-more-to-encourage-men-to-be-primary-school-teachers.html

MacDonald, A. (2014). 'Not for people like me?' Under-represented groups in science, technology and engineering A summary of the evidence: the facts, the fiction and what we should do next. Leeds: WISE Campaign.

Mahony, P. (1985). Schools for the Boys? Co-education Reassessed. London: Hutchinson.

Mallozzi, C. (2014). The personal has become political: A secondary teacher's perceptions of her body in the classroom. Journal of Pedagogy, 5(2), 183-207. 
Marchetti, M. and Raudma, T. (2010). Stocktaking 10 years of "Women in Science" policy by the European Commission 1999-2009. Brussels: European Commission.

McCormack, O. and Brownhill, S. (2014). 'Moving away from the caring': exploring the views of inservice and pre-service male teachers about the concept of the male teacher as a role model at an early childhood and post-primary level. International Journal of Academic Research in Education and Review, 2(4), 82-96. Retrieved on 27 May 2016 from: http://www.academicresearchjournals.org/IJARER/PDF\%202014/May/McCormack\%20and\%20Brow nhill.pdf

Meikle, J. (2007). Half school 'failures' are white working-class boys, says report. The Guardian, 22 June. Retrieved on 22 May 2016 from: http://www.theguardian.com/uk/2007/jun/22/education.schools Merton, R. (1957). Social theory and social structure. Glencoe: Free Press.

Millett, A. (1999). Valedictory Speech, Teacher Training Agency: Annual Review 1999. 19 May. London: Teacher Training Agency.

Mills, M. D. (2005). Gender relations: Success and backlash. In: B. Hoepper, J. Hennessey, P. Brown, D. Henderson and M. Mills (Eds.), Global voices: historical inquiries for the 21st century (pp. 195224). Milton, Queensland: John Wiley \& Sons.

Moreau, M. P. (2009). Comparer pour comprendre: la différentiation sexuée des parcours professionnels et familiaux des enseignant-e-s du second degré en France et en Angleterre. $\mathrm{PhD}$ thesis, Université de Toulouse Le Mirail and London Metropolitan University.

Moreau, M. P. (2011a). The Societal Construction of Boys' Underachievement in Educational Policies: A cross-national comparison. Journal of Education Policy, 26(2), 161-180.

Moreau, M. P. (2011b). Les enseignants et le genre. Paris: Presses Universitaires de France.

Moreau, M. P. (Ed.) (2014). Inequalities in the Teaching Profession: A global perspective. London: Palgrave McMillan.

Moreau, M. P., Osgood, J. \& Halsall, A. (2008). Equal opportunities policies in english schools: towards greater gender equality in the teaching workforce? Gender, Work and Organization, 15(6), 553-578.

Neugebauer, M., Helbig, M. and Landmann, A. (2010). Can the Teacher's Gender Explain 'Boy Crisis' in Educational Attainment? Retrieved on 9 July 2016 from: http://www.mzes.unimannheim.de/publications/wp/wp-133.pdf

Ofsted (1996). The gender divide. London: Ofsted.

Ofsted (2003a). Boys' achievement in secondary schools. London: Ofsted.

Ofsted (2003b). Yes he can: Schools where boys write well. London: Ofsted.

Oram, A. (1989). A master should not serve under a mistress: Women and men teachers 1900-1970, in Acker, S. (ed.) Teachers, gender and careers (pp. 21-34). London: Falmer Press.

Parsons, T. and Bales, R. F. (1955). Family, socialization and interaction process. New York:

The Free Press. 
Pepperell, S. and Smedley, S. (1998). Calls for more men in primary teaching: problematizing the issues. International Journal of Inclusive Education, 2(4), 341-357.

Pyke, N. (2000). Men shun careers in teaching. The Independent, March 12. Retrieved on 12 June 2016 from: www.independent.co.uk/student/postgraduate/mbas-guide/men-shun-careers-in-teaching697641.html

Raphael Reed, L. (1999). Troubling Boys and Disturbing Discourses on Masculinity and Schooling. Gender and Education, 11(1), 93-110.

Rezai-Rashti, G. M. and Martino, W. J. (2010). Black male teachers as role models: Resisting the homogenizing impulse of gender and racial affiliation, American Educational Research Journal, 47(1), 37-64.

Robb, M., Featherstone, B., Ruxton, S. and Ward, M. (2015). Beyond Male Role Models: gender identities and work with young men. Milton Keynes: The Open University. Retrieved on 27 May 2016 from: $\quad$ http://www.open.ac.uk/health-and-social-care/research/beyond-male-rolemodels/sites/www.open.ac.uk.health-and-social-care.research.beyond-male-rolemodels/files/files/BMRM_report.pdf

Robson, C. (1993). Real world research: A resource for social scientists and practitionerresearchers. Oxford: Blackwell.

Sharpe, S. (1976). Just Like a Girl: how girls learn to be women. London: Penguin.

Simpson, R. (2004). Masculinity at work: the experiences of men in female dominated occupations. Work, Employment and Society, 18(2), 349-368.

Skelton, C. (2002). The 'feminisation of schooling' or 're-masculinising' primary education? International Studies in Sociology of Education, 12(1), 77-96.

Skelton, C. and Francis, B. (2009). Feminism and 'the schooling scandal'. London: Routledge.

Skelton, C., Francis, B. and Valkanova, Y. (2007). Breaking Down the Stereotypes: Gender and Achievement in Schools. Manchester: Equal Opportunities Commission.

Spender, D. (1982). Invisible women. London: Writers and Readers Co-operative.

Stanworth, M. (1987). Girls on the margins: a study of gender divisions in the classroom. In G. Weiner and M. Arnot (Eds.) Gender under Scrutiny (pp. 95-128). London: Hutchinson.

Symeonidis, V. (2015). The Status of Teachers and the Teaching Profession A study of education unions’ perspectives. March. Brussels: Educational International. Retrieved on 2 July 2016 from: https://download.eiie.org/Docs/WebDepot/The\%20Status\%20of\%20Teachers\%20and\%20the\%20Teaching\%20Professio n.pdf

Tamboukou, M. (2003). Women, education and the self: A Foucauldian perspective. Basingstoke and New York: Palgrave Macmillan. 
Tarrant, A., Terry, G., Ward, M. R. M., Ruxton, S., Robb, M. and Featherstone, B. (2015). Are Male Role Models Really the Solution? Interrogating the 'War on Boys' Through the Lens of the 'Male Role Model’ Discourse. Boyhood Studies: An Interdisciplinary Journal, 8(1), 60-83.

Tashakkori, A. and Teddlie, C. (Eds.) (2003). Handbook of mixed methods in social and behavioral research. London: Sage Publications.

TDA (Training and Development Agency for Schools) (2007). Professional Standards for Qualified Teacher Status and Requirements for Initial Teacher Training. London: Training and Development Agency for Schools.

Walkerdine, V. (1990). Schoolgirl fictions. London: Verso.

Wansell, G. (2001). Genderquake. The Daily Mail, 21 April, 36. Retrieved on 19 September 2016 from: https://www.highbeam.com/doc/1G1-74931355.html

Weale, S. (2015). Boys trail girls in literacy and numeracy when starting school. The Guardian. Retrieved on 19 September 2016 from: https://www.theguardian.com/education/2015/oct/13/boystrail-girls-literacy-numeracy-when-starting-school

Woods, P. (1990). The Happiest Days? How Pupils Cope with School. Basingstoke: Falmer Press.

Younger, M. and Warrington, M. with Gray, J., Rudduck, J., McLellan, R., Bearne, E., Kershner, R. and Bricheno, P. (2005). Raising Boys’ Achievement. Research Report RR636. Nottingham: DfES. 